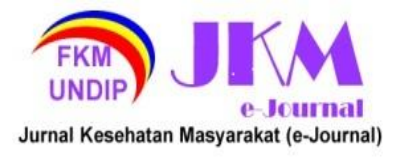

JURNAL KESEHATAN MASYARAKAT (e-Journal)
Volume 9, Nomor 6, November 2021
ISSN: 2715-5617 / e-ISSN: 2356-3346
http://ejournal3.undip.ac.id/index.php/jkm

\title{
HUBUNGAN INTENSITAS KEBISINGAN DI LINGKUNGAN KERJA DENGAN PENINGKATAN TEKANAN DARAH PADA PEKERJA PT X SEMARANG
}

\author{
Aqila Tischana Dewi ${ }^{*}$, Tri Joko², Yusniar Hanani Darundiati ${ }^{2}$ \\ ${ }_{1}^{1}$ Peminatan Kesehatan Lingkungan, Fakultas Kesehatan Masyarakat, Universitas Diponegoro, \\ JI. Prof. H. Soedarto, S.H.,Tembalang, Semarang, Indonesia \\ ${ }^{2}$ Bagian Kesehatan Lingkungan, Fakultas Kesehatan Masyarakat, Universitas Diponegoro, \\ JI. Prof. H. Soedarto, S.H.,Tembalang, Semarang, Indonesia \\ ${ }^{*}$ Corresponding author: tissawicaksono@gmail.com
}

\begin{abstract}
Noise from working environment can generate health impact on workers. Noise exposure which exceeds the treshold limit can affect the cardiovascular system, one of which is the increase of blood pressure. This research aims to determine the association between noise intensity and the increase of blood pressure on workers at PT X Semarang, a steel conduit manufacturing company. This is an observasional analitic study with cross-sectional design. The respondent amounted to 32 people taken with total sampling technique. The noise intensity measurement showed that the lowest noise intensity is in office area $(59,7 \mathrm{dBA})$ while the highest is in factory $B(88,12 \mathrm{dBA})$. The average age of the respondents is 40 years old with 8 years of working period. The average blood pressure before working is $124,06 / 81,34 \mathrm{mmHg}$ and after working is $126,97 / 82,84 \mathrm{mmHg}$ in which $71,9 \%$ respondents have an increase in systolic blood pressure and $68,8 \%$ in diastolic blood pressure. Bivariate analysis using fisher's exact test showed that there is an association between noise intensity and the increase of diastolic blood pressure $(p=0,013 ; R P=9,500 ; C l 95 \%=$ $1,641-54,994)$ but no association between noise intensity and the increase of systolic blood pressure $(p=$ $0,075 ; R P=5,938 ; \mathrm{Cl} 95 \%=1,084-32,513)$. Among the confounding variables, there was an association between smoking habit and the increase of diastolic blood pressure ( $p=0,022 ; R P=7,000 ; C l 95 \%=$ $1,185-41,359)$ but not with the increase of systolic blood pressure $(\mathrm{p}=0,433 ; \mathrm{RP}=2,600 ; \mathrm{Cl} 95 \%=0,518$ 13,041). The conclusion of this research is noise intensity and smoking habit can affect the increase of diastolic blood pressure. The workers are advised to wear earplugs when working.
\end{abstract}

Keywords : noise intensity, blood pressure, industrial workers

\section{PENDAHULUAN}

Kemajuan yang pesat di sektor industri memiliki peranan penting dalam pembangunan negara. Pada tahun 2018, tercatat bahwa terdapat sebanyak 4.378 industri skala menengah besar yang tersebar di Provinsi Jawa Tengah. Kota Semarang memegang peringkat pertama sebagai kota dengan perusahaan industri menengah dan besar terbanyak di Provinsi Jawa Tengah dengan jumlah perusahaan sebanyak 501 perusahaan. ${ }^{1}$

Namun, penggunaan mesin-mesin besar dan canggih di industri juga memberikan dampak negatif berupa kebisingan. Paparan kebisingan dapat menimbulkan gangguan pada kesehatan masyarakat mulai dari gangguan pendengaran hingga gangguan kardiovaskuler akibat tekanan darah yang meningkat. ${ }^{2}$ Penyakit hipertensi atau tekanan darah tinggi menempati proporsi terbesar di antara jenis penyakit tidak menular di Jawa Tengah pada tahun 2019 yaitu sebesar $68,6 \%$ dengan total perkiraan penderita hipertensi berusia 15 tahun keatas sebanyak 8.070.378 orang. $^{3}$

Penelitian yang pernah dilakukan sebelumnya menunjukkan adanya peningkatan tekanan darah dan denyut nadi secara signifkan sebelum dan sesudah bekerja dalam paparan kebisingan dengan intensitas 98,1 dBA pada pekerja pabrik kayu. ${ }^{4}$ Penelitian lain juga membuktikan bahwa terdapat peningkatan tekanan darah pekerja antara sebelum dan sesudah bekerja dimana rata-rata pekerja memiliki tekanan darah normal sebelum bekerja dan tekanan darah sesudah bekerja dalam paparan kebisingan diatas $85 \mathrm{dBA}$ menunjukkan gejala pre-hipertensi. ${ }^{5}$ Paparan kebisingan memicu terjadinya gangguan sistem fisiologis jaringan otot tubuh yang menyebabkan ketidakstabilan emosi sehingga memacu kerja jantung dalam memompa darah ke seluruh tubuh. Hal inilah yang membuat tekanan darah seseorang meningkat dan menimbulkan hipertensi. ${ }^{6}$ 


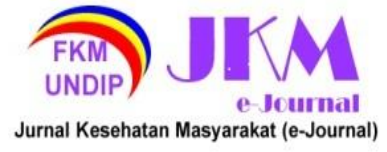

PT X Semarang merupakan perusahaan manufaktur conduit baja dan sistem pendukung kabel. Fasilitas produksi yang dimiliki oleh perusahaan ini terdiri dari 46 mesin yang menurut hasil pengukuran yang pernah dilakukan sebelumnya menimbulkan intensitas kebisingan hingga $90 \mathrm{dBA}$. Penelitian ini dilakukan untuk melihat hubungan antara intensitas kebisingan dengan peningkatan tekanan darah pada pekerja PT X Semarang.

\section{METODE PENELITIAN}

Penelitian ini menggunakan jenis penelitian observasional analitik dengan pendekatan cross sectional. Populasi dalam penelitian ini adalah seluruh pekerja PT $X$
Semarang sejumlah 32 orang. Pemilihan sampel ditentukan dengan metode total sampling. Variabel yang diukur diantaranya intensitas kebisingan, peningkatan tekanan darah pada pekerja, dan variabel pengganggu yang terdiri dari umur, jenis kelamin, masa kerja, jenis kelamin, status gizi, kebiasaan merokok, kebiasaan mengonsumsi alkohol, dan riwayat hipertensi keluarga. Pengumpulan data dilakukan dengan pengukuran intensitas kebisingan di area kerja menggunakan sound level meter, pengukuran tekanan darah menggunakan tensimeter digital, dan wawancara menggunakan kuesioner. Pengolahan dan analisis data dilakukan dengan uji Chi Square dan Fisher's Exact Test.

HASIL DAN PEMBAHASAN

A. Analisis Univariat

Tabel 1. Distribusi Frekuensi Pekerja PT X Semarang

\begin{tabular}{|c|c|c|c|c|}
\hline No. & Variabel & Kategori & Frekuensi & $\%$ \\
\hline 1. & Umur $=$ & $\begin{array}{l}\geq 40 \text { tahun } \\
<40 \text { tahun }\end{array}$ & $\begin{array}{l}17 \\
15\end{array}$ & $\begin{array}{l}53,1 \\
46,9\end{array}$ \\
\hline 2. & Jenis Kelamin & $\begin{array}{l}\text { Laki-laki } \\
\text { Perempuan }\end{array}$ & $\begin{array}{c}25 \\
7\end{array}$ & $\begin{array}{l}78,1 \\
21,9\end{array}$ \\
\hline 3. & Masa Kerja & $\begin{array}{l}\geq 6,5 \text { tahun } \\
<6,5 \text { tahun }\end{array}$ & $\begin{array}{l}16 \\
16\end{array}$ & $\begin{array}{l}50 \\
50\end{array}$ \\
\hline 4. & Area Kerja & $\begin{array}{l}\text { Pabrik A } \\
\text { Pabrik B } \\
\text { Kantor }\end{array}$ & $\begin{array}{l}\frac{14}{9} \\
9\end{array}$ & $\begin{array}{l}28,1 \\
43,8 \\
28,1\end{array}$ \\
\hline 5. & Status Gizi & $\begin{array}{l}\text { Kurus (underweight) } \\
\text { Gemuk (overweight) } \\
\text { Normal }\end{array}$ & $\begin{array}{c}5 \\
5 \\
22\end{array}$ & $\begin{array}{l}15,6 \\
15,6 \\
68,8\end{array}$ \\
\hline 6. & Kebiasaan Merokok & $\begin{array}{l}\text { Ya } \\
\text { Tidak }\end{array}$ & $\begin{array}{l}16 \\
16\end{array}$ & $\begin{array}{l}50 \\
50\end{array}$ \\
\hline 7. & Kebiasaan Mengonsumsi Alkohol & $\begin{array}{l}\text { Ya } \\
\text { Tidak }\end{array}$ & $\begin{array}{c}6 \\
26\end{array}$ & $\begin{array}{l}18,8 \\
81,2\end{array}$ \\
\hline 8. & Riwayat Hipertensi Keluarga & $\begin{array}{l}\text { Ya } \\
\text { Tidak }\end{array}$ & $\begin{array}{l}12 \\
20\end{array}$ & $\begin{array}{l}37,5 \\
62,5 \\
\end{array}$ \\
\hline
\end{tabular}

Sebagian besar responden berumur lebih dari 40 tahun yaitu sebanyak 17 orang $(53,1 \%)$ dengan rentang umur 19-66 tahun dan rata-rata berumur 40 tahun, berjenis kelamin laki-laki yaitu sebanyak 25 orang $(78,1 \%)$, memiliki masa kerja 6,5 tahun atau lebih yaitu sebanyak 16 orang $(50 \%)$ dengan rentang masa kerja 4 bulan sampai 22 tahun dan rata-rata masa kerja 8 tahun, bekerja di area kerja dengan kebisingan lebih dari $85 \mathrm{dBA}$ yaitu sebanyak 23 orang $(71,9 \%)$, memiliki status gizi normal yaitu sebanyak 22 orang $(68,8 \%)$, memiliki kebiasaan merokok yaitu sebanyak 16 orang (50\%), tidak memiliki kebiasaan mengonsumsi alkohol yaitu sebanyak 26 orang $(81,2 \%)$, dan tidak memiliki riwayat hipertensi di keluarga yaitu sebanyak 20 orang $(62,5 \%)$.

B. Pengukuran Intensitas Kebisingan Tabel 2. Hasil Pengukuran Intensitas Kebisingan di Lingkungan Kerja PT $X$ Semarang

\begin{tabular}{ccc}
\hline No. & Area Kerja & $\begin{array}{c}\text { Intensitas } \\
\text { Kebisingan }\end{array}$ \\
\hline 1. & Pabrik A & $86,36 \mathrm{dBA}$ \\
2. & Pabrik B & $88,12 \mathrm{dBA}$ \\
3. & Kantor & $59,7 \mathrm{dBA}$ \\
\hline
\end{tabular}




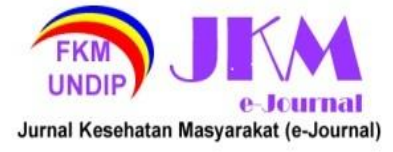

Tabel 2 menunjukkan bahwa dari 3 area kerja di PT X Semarang, sebanyak 2 area kerja memiliki intensitas kebisingan melebihi NAB 85 $\mathrm{dBA}$ yaitu pabrik $\mathrm{A}(86,36 \mathrm{dBA})$ dan pabrik $\mathrm{B}$ $(88,12 \mathrm{dBA})$

C. Pengukuran Tekanan Darah

Tabel 3. Hasil Pengukuran Tekanan Darah Pekerja PT X Semarang

Tekanan Perubahan Tekanan Darah

Darah Meningkat Tidak Meningkat

Jum \% Jum \%

lah $\quad$ lah
JURNAL KESEHATAN MASYARAKAT (e-Journal)

Volume 9, Nomor 6, November 2021

ISSN: 2715-5617 / e-ISSN: 2356-3346

http://ejournal3.undip.ac.id/index.php/jkm

D. Analisis Bivariat

1. Hubungan Intensitas Kebisingan, Umur, Jenis Kelamin, dan Masa Kerja dengan Peningkatan Tekanan Darah Sistolik

Tabel 4. Hubungan Intensitas Kebisingan, Umur, Jenis Kelamin, dan Masa Kerja dengan Peningkatan Tekanan Darah Sistolik pada Pekerja PT X Semarang

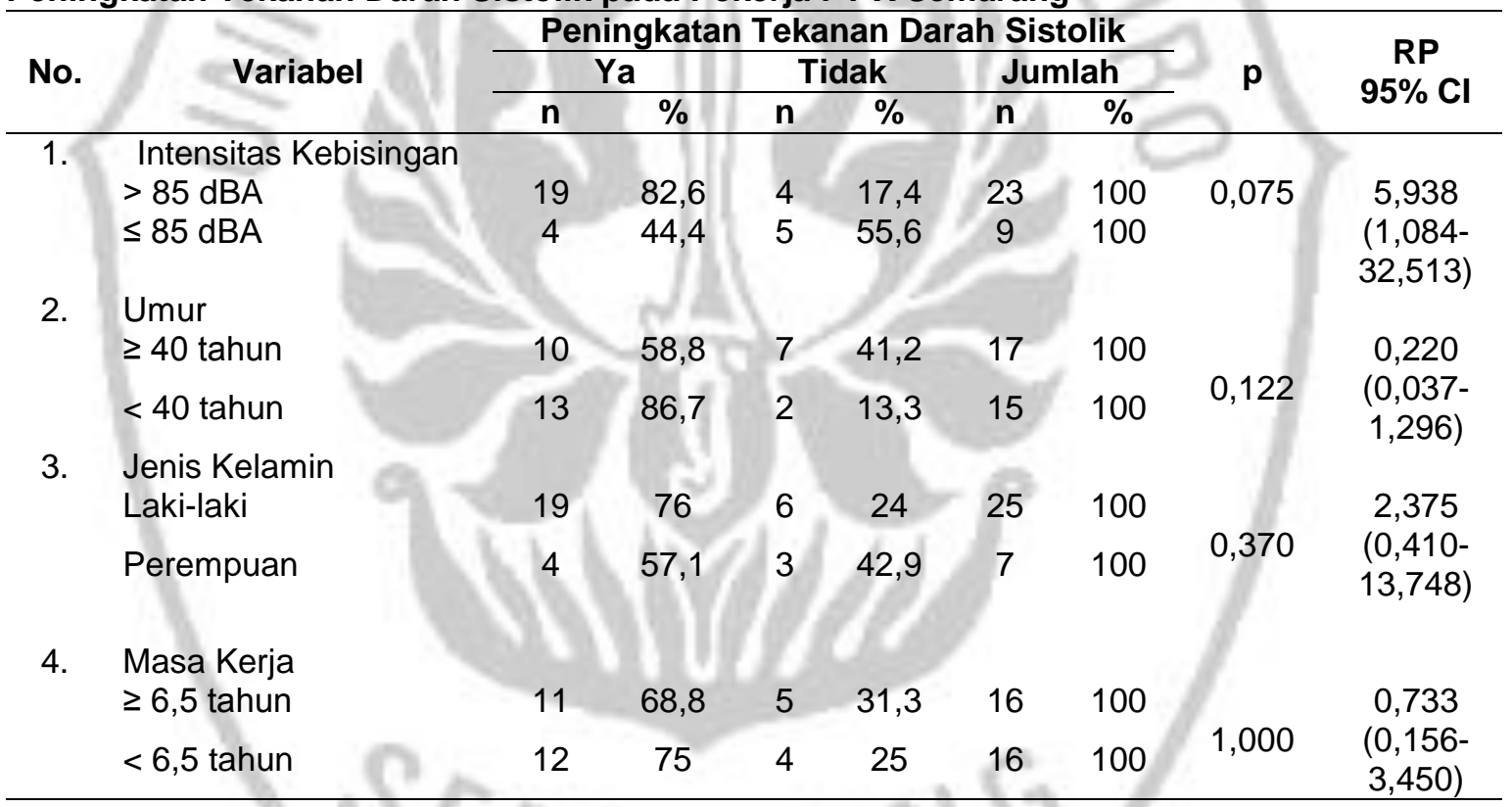

Berdasarkan tabel 4 dapat diketahui bahwa tidak ada hubungan antara variabel intensitas kebisingan, umur, jenis kelamin, dan masa kerja dengan peningkatan tekanan darah sistolik. 


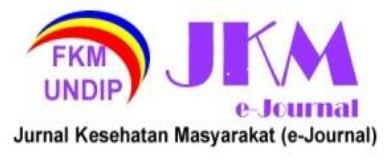

JURNAL KESEHATAN MASYARAKAT (e-Journal)
Volume 9, Nomor 6, November 2021
ISSN: 2715-5617 / e-ISSN: 2356-3346
http://ejournal3.undip.ac.id/index.php/jkm

2. Hubungan Intensitas Kebisingan, Umur, Jenis Kelamin, dan Masa Kerja dengan Peningkatan Tekanan Darah Diastolik

Tabel 5. Hubungan Intensitas Kebisingan, Umur, Jenis Kelamin, dan Masa Kerja dengan Peningkatan Tekanan Darah Diastolik pada Pekerja PT X Semarang

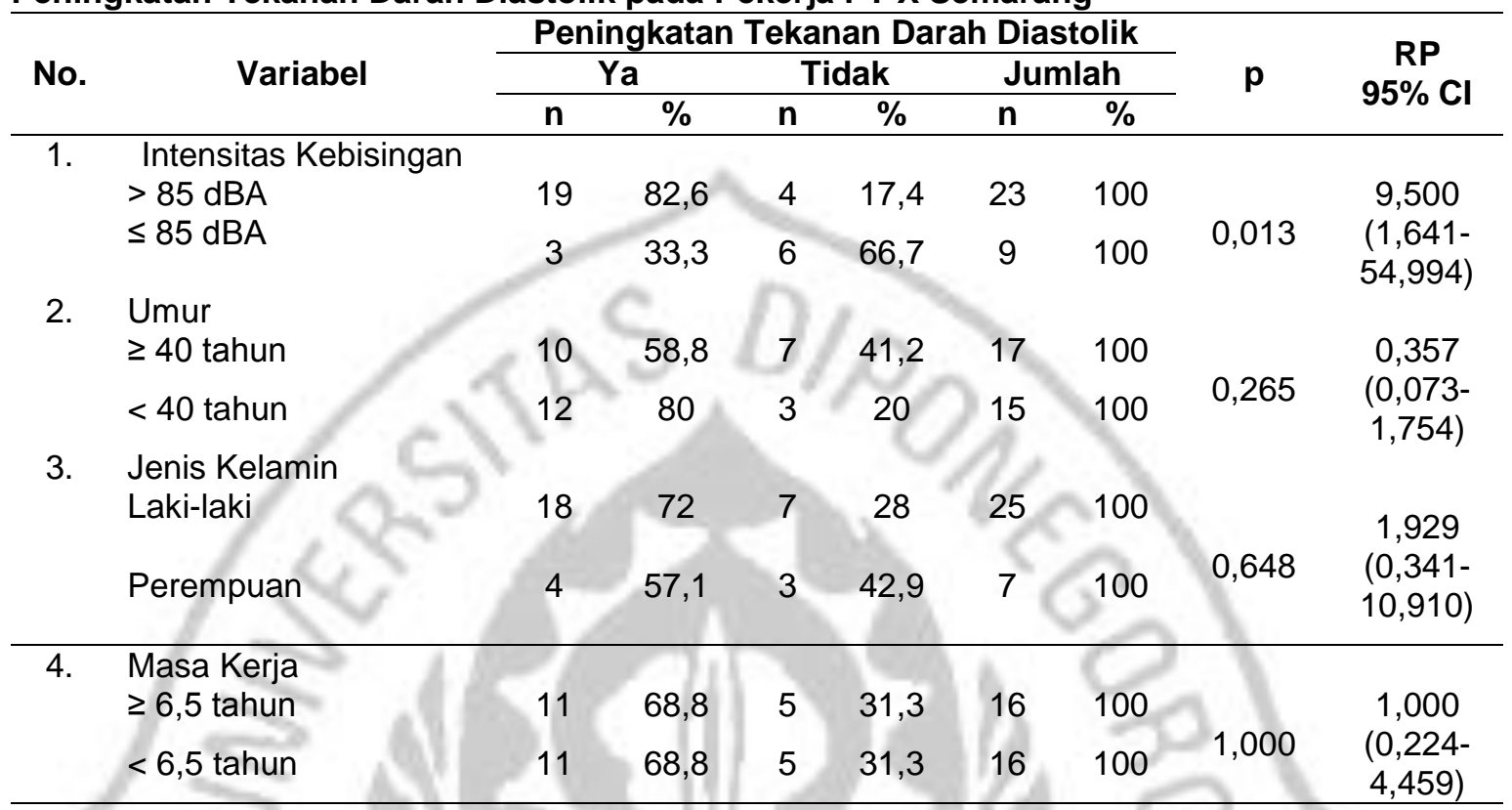

Berdasarkan tabel 5 dapat diketahui bahwa ada hubungan antara intensitas kebisingan dengan peningkatan tekanan darah diastolik $(p=0,013 ; \mathrm{RP}=9,500)$ namun tidak ada hubungan antara umur, jenis kelamin, dan masa kerja dengan peningkatan tekanan darah diastolik.

3. Hubungan Status Gizi, Kebiasaan Merokok, Kebiasaan Mengonsumsi Alkohol, dan Riwayat Hipertensi Keluarga dengan Peningkatan Tekanan Darah Sistolik

Tabel 6. Hubungan Status Gizi, Kebiasaan Merokok, Kebiasaan Mengonsumsi Alkohol, dan Riwayat Hipertensi Keluarga dengan Peningkatan Tekanan Darah Sistolik pada Pekerja PT X Semarang

\begin{tabular}{|c|c|c|c|c|c|c|c|c|c|}
\hline \multirow{3}{*}{ No. } & \multirow{3}{*}{ Variabel } & \multicolumn{6}{|c|}{ Peningkatan Tekanan Darah Sistolik } & \multirow{3}{*}{$\mathbf{p}$} & \multirow{3}{*}{$\begin{array}{c}\text { RP } \\
95 \% \mathrm{Cl}\end{array}$} \\
\hline & & & & & ak & & & & \\
\hline & & $n$ & $\%$ & $n$ & $\%$ & $\mathrm{n}$ & $\%$ & & \\
\hline \multirow[t]{3}{*}{1.} & Status Gizi & & & & & & & \multirow[b]{3}{*}{1,000} & \multirow{3}{*}{$\begin{array}{c}1,089 \\
(0,215- \\
5,519)\end{array}$} \\
\hline & Kurang Baik & 7 & 70 & 3 & 30 & 10 & 100 & & \\
\hline & Normal & & & 7 & & 22 & 100 & & \\
\hline \multirow[t]{3}{*}{2.} & Kebiasaan Me & 14 & 875 & 2 & 125 & 16 & 100 & \multirow{3}{*}{0,022} & \multirow{3}{*}{$\begin{array}{r}7,000 \\
(1,185- \\
41,359)\end{array}$} \\
\hline & Tidat & & & & & 10 & 100 & & \\
\hline & Tidak & 8 & 50 & & 50 & 16 & 100 & & \\
\hline \multirow[t]{3}{*}{3.} & $\begin{array}{l}\text { Kebiasaan } \\
\text { Mengonsumsi Alkohol }\end{array}$ & & & & & & & & \\
\hline & Ya & 5 & 83,3 & 1 & 16,7 & 6 & 100 & \multirow{2}{*}{0,648} & \multirow{2}{*}{$\begin{array}{c}2,222 \\
(0,222- \\
22,229)\end{array}$} \\
\hline & Tidak & 18 & 69,2 & 8 & 30,8 & 26 & 100 & & \\
\hline
\end{tabular}

4. Riwayat Hipertensi

Keluarga 


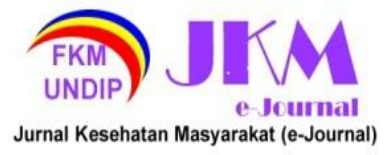

JURNAL KESEHATAN MASYARAKAT (e-Journal)

Volume 9, Nomor 6, November 2021

ISSN: 2715-5617 / e-ISSN: 2356-3346

http://ejournal3.undip.ac.id/index.php/jkm

\begin{tabular}{|c|c|c|c|c|c|c|c|c|c|}
\hline \multirow{3}{*}{ No. } & \multirow{3}{*}{ Variabel } & \multicolumn{6}{|c|}{ Peningkatan Tekanan Darah Sistolik } & \multirow{3}{*}{$p$} & \multirow{3}{*}{$\begin{array}{c}\text { RP } \\
95 \% \mathrm{Cl}\end{array}$} \\
\hline & & \multicolumn{2}{|c|}{ Ya } & \multicolumn{2}{|c|}{ Tidak } & \multicolumn{2}{|c|}{ Jumlah } & & \\
\hline & & $\mathbf{n}$ & $\%$ & $\mathbf{n}$ & $\%$ & $\mathrm{n}$ & $\%$ & & \\
\hline & Ada & 4 & 66,7 & 2 & 33,3 & 6 & 100 & \multirow{2}{*}{1,000} & \multirow{2}{*}{$\begin{array}{r}0,889 \\
(0,134- \\
5,888)\end{array}$} \\
\hline & Tidak Ada & 18 & 69,2 & 8 & 30,8 & 26 & 100 & & \\
\hline
\end{tabular}

Berdasarkan tabel 6 dapat diketahui bahwa tidak ada hubungan antara status gizi, kebiasaan merokok, kebiasaan mengonsumsi alkohol, dan riwayat hipertensi keluarga dengan peningkatan tekanan darah sistolik.

4. Hubungan Status Gizi, Kebiasaan Merokok, Kebiasaan Mengonsumsi Alkohol, dan Riwayat Hipertensi Keluarga dengan Peningkatan Tekanan Darah Diastolik

Tabel 7. Hubungan Status Gizi, Kebiasaan Merokok, Kebiasaan Mengonsumsi Alkohol, dan Riwayat Hipertensi Keluarga dengan Peningkatan Tekanan Darah Diastolik pada Pekerja PT X Semarang

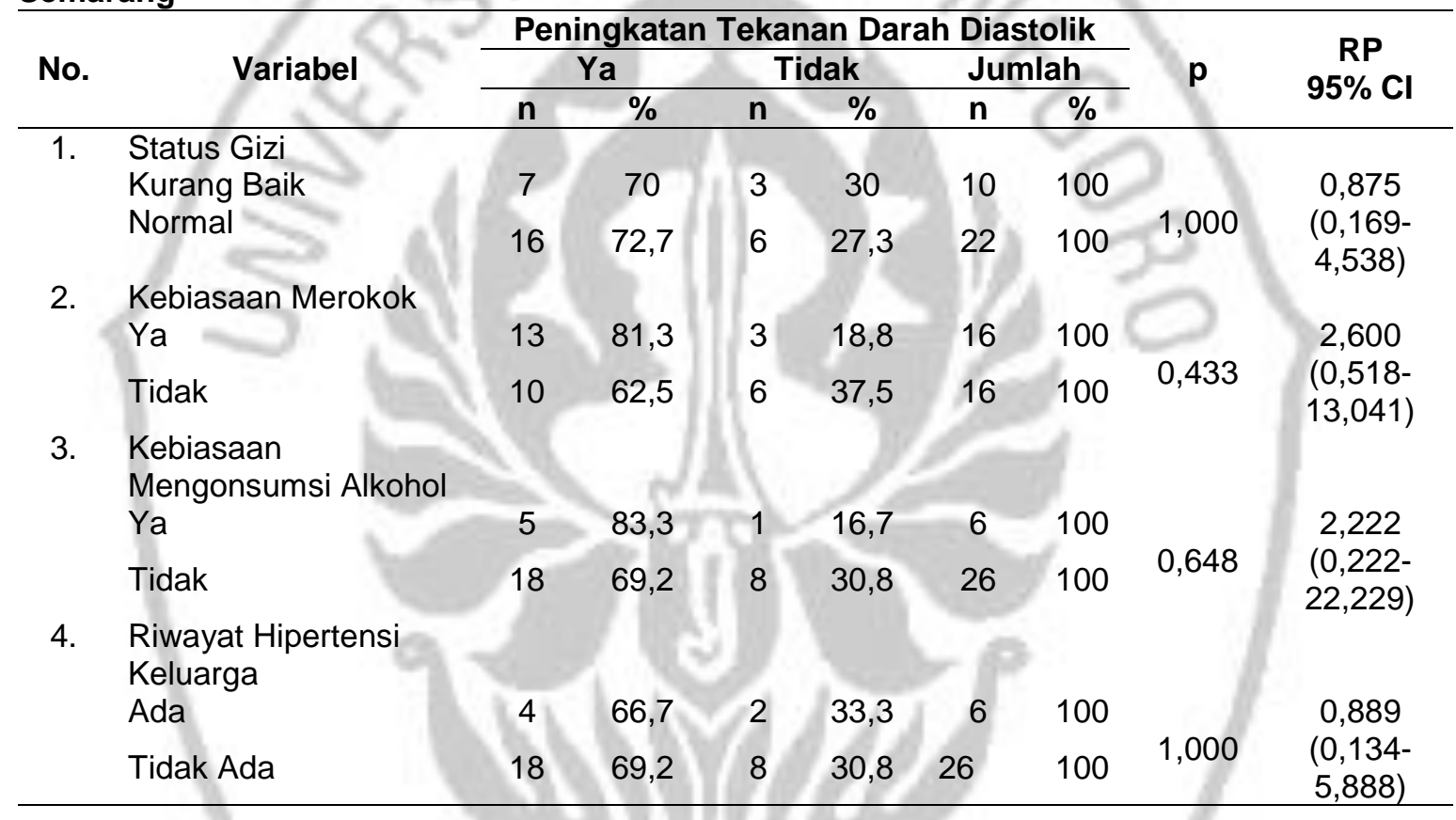

Berdasarkan tabel 7 dapat diketahui bahwa ada hubungan antara kebiasaan merokok dengan peningkatan tekanan darah diastolik $(p=0,022 ; R P=7,000)$ namun tidak ada hubungan antara status gizi, kebiasaan mengonsumsi alkohol, dan riwayat hipertensi keluarga dengan peningkatan tekanan darah diastolik.

\section{Hubungan Intensitas Kebisingan dengan Peningkatan Tekanan Darah}

Kebisingan merupakan salah satu komponen lingkungan yang perlu dikendalikan di lingkungan kerja untuk meminimalisir risiko timbulnya gangguan kesehatan pada pekerja. Beberapa faktor yang menimbulkan kebisingan di industri adalah mesin, karakteristik bangunan, dan iklim. ${ }^{7}$ Perbedaan intensitas kebisingan di masing-masing area disebabkan karena kegiatan produksi yang berbeda dan penggunaan mesin-mesin yang berbeda pula. Pemanfaatan barrier (penghalang) dapat mengurangi frekuensi kebisingan, barrier dibuat setinggi manusia agar bising terpantul keatas sehingga mengurangi kebisingan di sekitar. ${ }^{8}$

Hasil uji bivariat pada tekanan darah sistolik menunjukkan nilai $p=0,075$ ( $p>$ $0,05)$ dan $\mathrm{RP}=5,938 ; 95 \% \mathrm{Cl}(1,084-$ 


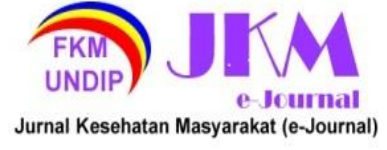

32,513) RP > 1, sehingga dapat disimpulkan bahwa tidak ada hubungan yang signifikan antara intensitas kebisingan dengan peningkatan tekanan darah sistolik pada pekerja PT X Semarang. Sedangkan pada tekanan darah diastolik, didapatkan nilai $\mathrm{p}=$ $0,013(\mathrm{p}<0,05)$ dan RP $=9,500 ; 95 \% \mathrm{Cl}$ $(1,641-54,994) \mathrm{RP}>1$, sehingga dapat disimpulkan bahwa ada hubungan yang signifikan antara intensitas kebisingan dengan peningkatan tekanan darah diastolik pada pekerja PT X Semarang. Nilai rasio prevalensi menunjukkan bahwa pekerja yang bekerja di area dengan intensitas kebisingan di atas $85 \mathrm{dBA}$ memiliki peluang 5,938 kali lebih besar untuk mengalami peningkatan tekanan darah sistolik dan 9,5 kali lebih besar untuk mengalami peningkatan tekanan darah diastolik dibandingkan pekerja yang bekerja di area dengan intensitas kebisingan di bawah 85 dBA.

Hal tersebut dikarenakan paparan kebisingan yang tinggi memicu terjadinya penyempitan pembuluh darah sehingga menghambat aliran darah dimana jumlah darah yang diedarkan menjadi lebih sedikit dari kondisi normal dan otot jantung menjadi lebih kaku sehingga tekanan saat otot jantung berelaksasi menjadi lebih tinggi, keadaan itulah yang membuat tekanan darah diastolik meningkat. ${ }^{9}$ Beban kerja yang berbeda diantara pekerja di masingmasing area memberikan pengaruh yang berbeda pula pada peningkatan tekanan darah.

Paparan kebisingan yang kronis dapat mempengaruhi sistem metabolisme dan kardiovaskuler dengan peningkatan faktor risiko penyakit kardiovaskuler seperti tekanan darah, kadar lemak darah, dan kadar gula darah. ${ }^{2}$ Reaksi emosional yang dirasakan seseorang berupa ketidaknyamanan akibat paparan kebisingan memicu produksi epinefrin dan norepinefrin yang memacu jantung untuk memompa darah lebih cepat dan menstimulasi peningkatan tekanan darah sehingga meningkatkan risiko hipertensi. ${ }^{6}$ Penggunaan earplugs saat bekerja dapat mengurangi risiko gangguan kesehatan yang disebabkan oleh paparan kebisingan yang tinggi.

\section{Hubungan Umur dengan Peningkatan Tekanan Darah}

Hasil uji analisis bivariat menunjukkan tidak ada hubungan antara umur dengan peningkatan tekanan darah. Hal ini dikarenakan pada penelitian ini jumlah pekerja yang berumur lebih dari 40 tahun dan mengalami peningkatan tekanan darah yaitu sebanyak 10 orang $(58,8 \%)$ tidak berbeda jauh dengan yang tidak mengalami peningkatan tekanan darah yaitu sebanyak 7 orang $(41,2 \%)$. Hasil penelitian ini sejalan dengan penelitian Raihan yaitu tidak terdapat hubungan yang bermakna antara umur dengan status tekanan darah. ${ }^{10}$ Namun penelitian ini tidak sejalan dengan hasil penelitian Widyatama. ${ }^{11}$ Pertambahan umur menyebabkan peningkatan tekanan arterial, regurgitasi aorta atau ketidakmampuan katup aorta untuk tertutup rapat, serta proses degeneratif sehingga memicu peningkatan tekanan darah. ${ }^{12}$ Seiring bertambahnya umur, risiko seseorang untuk terkena hipertensi menjadi semakin besar.

\section{Hubungan Jenis Kelamin dengan Peningkatan Tekanan Darah}

Hasil uji analisis bivariat menunjukkan tidak ada hubungan antara jenis kelamin dengan peningkatan tekanan darah. Dalam penelitian ini, sebagian besar pekerja yang berjenis kelamin laki-laki mengalami peningkatan tekanan darah sistolik $(76 \%)$ dan diastolik (72\%). Hasil tersebut didukung oleh studi yang menyatakan bahwa laki-laki pada umur produktif umumnya lebih berisiko untuk menderita hipertensi dibandingkan perempuan. Sedangkan pada perempuan, risiko hipertensi akan lebih besar pada saat lansia dikarenakan hormon estrogen pada perempuan memiliki peran dalam meningkatkan kadar High Density Lipoprotein (HDL) sehingga mencegah terjadinya penyempitan pembuluh darah arteri. ${ }^{13}$

Hasil tersebut sesuai dengan penelitian Anggara dan Prayitno yang menyatakan tidak adanya hubungan antara jenis kelamin dengan tekanan darah. ${ }^{14}$ Namun penelitian ini tidak sejalan dengan Garwahusada yang menyatakan adanya hubungan antara jenis kelamin dan peningkatan tekanan darah. ${ }^{15}$ Meskipun demikian, jenis kelamin bukanlah 


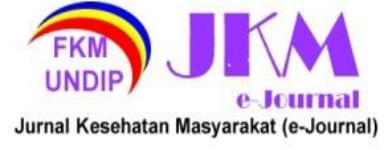

faktor utama yang mempengaruhi tekanan darah seseorang karena masih ada faktorfaktor yang dapat diubah yang mempengaruhi tekanan darah.

\section{Hubungan Masa Kerja dengan Peningkatan Tekanan Darah \\ Hasil uji analisis bivariat menunjukkan} tidak ada hubungan antara masa kerja dengan peningkatan tekanan darah. Hal ini terjadi karena paparan kebisingan yang diterima pekerja selama masa kerjanya hanya bersifat sementara serta tidak terus menerus meningkat dan terakumulasi dari waktu ke waktu sebab tekanan darah dapat kembali menjadi normal ketika beristirahat. Hasil penelitian ini tidak sejalan dengan penelitian Muchsin yang menunjukkan bahwa terdapat hubungan antara masa kerja dengan tekanan darah sistolik. ${ }^{4}$ Paparan kebisingan yang terus-menerus menimbulkan gangguan terhadap kondisi emosional seseorang yang memicu stress pada sistem saraf otonom, kelenjar pituitary, dan kelenjar adrenal sehingga menyebabkan perubahan tekanan darah. ${ }^{16}$

\section{Hubungan Status Gizi dengan Peningkatan Tekanan Darah}

Hasil uji analisis bivariat menunjukkan bahwa status gizi tidak berhubungan dengan peningkatan tekanan darah. Hal tersebut dikarenakan sebagian besar responden dalam penelitian ini memiliki status gizi normal $(68,8 \%)$ sehingga tidak berhasil membuktikan adanya hubungan antara keduanya, kemudian peningkatan tekanan darah pada responden lebih banyak dipengaruhi oleh faktor-faktor lain yang tidak diteliti dalam penelitian ini seperti aktivitas fisik, asupan nutrisi, dan tingkat stress. Hasil tersebut tidak sejalan dengan Muchsin yang menemukan adanya hubungan diantara kedua variabel. ${ }^{4}$ Semakin besar massa tubuh seseorang, semakin besar pula jumlah darah yang beredar ke seluruh tubuh untuk menyebarkan oksigen. Seseorang yang kelebihan berat badan memiliki jaringan lemak yang tebal di bawah kulit yang berisiko mempersempit pembuluh darah sehingga menghambat aliran darah ke seluruh tubuh. Dalam memenuhi jumlah kebutuhan darah, jantung akan memompa darah lebih cepat dan tekanan darah akan meningkat. ${ }^{17}$

\section{Hubungan Kebiasaan Merokok dengan Peningkatan Tekanan Darah}

Hasil uji bivariat menunjukkan tidak ada hubungan antara kebiasaan merokok dengan peningkatan tekanan darah sistolik dengan nilai $p=0,433(p>0,05)$ dan $R P=$ 2,600 (RP > 1); 95\% Cl (0,518-13,041). Namun ada hubungan antara kebiasaan merokok dengan peningkatan tekanan darah diastolik dengan nilai $p=0,022(p<$ $0,05)$ dan $\mathrm{RP}=7,000(\mathrm{RP}>1) ; 95 \% \mathrm{Cl}$ $(1,185-41,359)$. Nilai rasio prevalensi menunjukkan bahwa pekerja yang memiliki kebiasaan merokok memiliki peluang 2,6 kali lebih besar untuk mengalami peningkatan tekanan sistolik dan 7 kali lebih besar untuk mengalami peningkatan tekanan darah diastolik.

Hal ini terjadi karena zat toksik pada rokok menyebabkan terjadinya aterosklerosis dan mempersempit aliran darah pada pembuluh, akibatnya aliran darah menjadi terhambat sehingga membuat otot jantung menjadi cenderung kaku pada saat relaksasi. Kondisi inilah yang membuat tekanan darah diastolik menjadi tinggi. ${ }^{18}$

Merokok merupakan faktor risiko penyakit kardiovaskuler. Kebiasaan merokok seringkali dikaitkan dengan serangan jantung sebab rokok mengandung nikotin yang memicu peningkatan hormon adrenalin yang dapat meningkatkan tekanan darah dan kadar kolesterol dalam darah yang mampu memicu penyakit jantung.

\section{Hubungan Kebiasaan Mengonsumsi Alkohol dengan Peningkatan Tekanan Darah}

Hasil uji analisis bivariat menunjukkan tidak ada hubungan antara kebiasaan mengonsumsi alkohol dengan peningkatan tekanan darah. Hal ini dikarenakan sebagian besar responden $(81,2 \%)$ tidak memiliki kebiasaan mengonsumsi alkohol. Pengaruh alkohol terhadap tekanan darah tergantung dari kandungan alkohol dalam minuman yang dikonsumsi, jumlah alkohol yang dikonsumsi, dan seberapa sering mengonsumsi. ${ }^{19}$ 


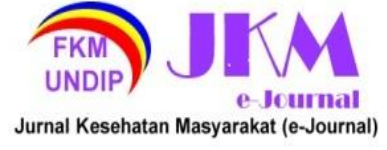

Penelitian ini tidak sejalan dengan penelitian milik Susiani. Konsumsi alkohol dapat memicu hipertensi karena alkohol memiliki efek yang sama dengan karbon monoksida sehingga kadar keasaman darah meningkat dan menyebabkan darah menjadi kental sehingga memaksa kerja jantung untuk memompa darah lebih kuat. ${ }^{20}$

\section{Hubungan Riwayat Hipertensi Keluarga dengan Peningkatan Tekanan Darah}

Hasil uji analisis bivariat menunjukkan tidak ada hubungan antara riwayat hipertensi keluarga dengan peningkatan tekanan darah. Hal ini dikarenakan sebagian besar responden (62,5\%) tidak memiliki riwayat hipertensi keluarga.

Penelitian ini tidak sejalan dengan penelitian Hakim. ${ }^{13}$ Seseorang yang memiliki riwayat hipertensi dari keluarganya memiliki kemungkinan untuk menderita hipertensi juga. Perbedaan hasil tersebut disebabkan karena faktor risiko peningkatan tekanan darah tidak hanya berasal dari faktor genetik namun juga faktor-faktor yang dapat diubah lainnya seperti diet, pola hidup, dan kelainan metabolik lainnya.

\section{KESIMPULAN}

Ada hubungan antara intensitas kebisingan di area kerja $(p=0,013, R P=9,500)$ dan kebiasaan merokok ( $p=0,022$; $R P=7,000)$ dengan peningkatan tekanan darah diastolik pada pekerja PT X Semarang.

\section{SARAN}

1. Bagi Perusahaan

a. Menyediakan APD (Alat Pelindung Diri) berupa earplugs untuk pekerja pabrik serta mewajibkan penggunaannya.

b. Mengukur intensitas kebisingan secara rutin dan mengupayakan pengendalian kebisingan di lingkungan kerja dengan memanfaatkan barrier.

2. Bagi Pekerja

a. Menggunakan APD berupa earplugs.

b. Melaksanakan cek kesehatan rutin untuk memantau tekanan darah.

\section{DAFTAR PUSTAKA}

1. Badan Pusat Statistik Provinsi Jawa Tengah. Statistik Industri Manufaktur Besar Sedang Provinsi Jawa Tengah 2018 Buku I. Semarang: Badan Pusat Statistik Provinsi
Jawa Tengah; 2020. 81 p.

2. Babisch W. Cardiovascular Effects of Noise. Noise Heal. 2011;13(52).

3. Dinas Kesehatan Provinsi Jawa Tengah. Profil Kesehatan Provinsi Jateng Tahun 2019. Dinas Kesehatan Provinsi Jawa Tengah. Semarang: Dinas Kesehatan Provinsi Jawa Tengah; 2019.

4. Muchsin, Haryono, Rosyidah. Hubungan Karakteristik Pekerja Dengan Tekanan Darah Pekerja Wanita Terpapar Bising Shift Pagi di Bagian Weaving (Tenun) "Agung Saputra Tex" Piyungan Bantul Yogyakarta. Kes Mas. 2010;4(3):144-239.

5. Siswati, Adriyani R. Hubungan Pajanan Kebisingan dengan Tekanan Darah dan Denyut Nadi pada Pekerja Industri Kemasan Semen. J Kesehat Lingkung Indones. 2017;16(1):29-36.

6. Zulharmans, Russeng S, Wahyuni A. Hubungan Kebisingan Pada Tekanan Darah Pada Karyawan Bagian Produksi PT.Semen Tonasa. J Media Kesehat. 2015;

7. Cao H, Kang T, Chen X. Noise analysis and sources identification in machine tool spindles. CIRP J Manuf Sci Technol. 2019;25:26-35.

8. Fahlevi A, Emra D. Perbaikan Tingkat Kebisingan Kerja Pada Area Produksi PT Bumi Karya Saranamas. J Baut dan Manufaktur. 2020;2(2):1-8.

9. Sasongko DP. Kebisingan Lingkungan. Semarang: Badan Penerbit Universitas Diponegoro Semarang; 2000.

10.Raihan LN, Erwin, Dewi AP. Faktor-faktor yang Berhubungan dengan Kejadian Hipertensi Primer Pada Masyarakat di Wilayah Kerja Puskesmas Rumbai Pesisir. JOM PSIK. 2014;1(2):1-10.

11.Widyatama HG, Kusumaningrum D, Widyasyifa SA, Rahmayanti D, Gondoyuwono $\mathrm{H}$. Usia dan jumlah rokok meningkatkan tekanan darah. IIm Kesehat IQRA. 2020;8(2):69-76.

12.Aristoteles. Korelasi Umur dan Jenis Kelamin Dengan Penyakit Hipertensi di Emergency Center Unit Rumah Sakit Islam Siti Khadijah Palembang 2017. Indones J Perawat. 2018;3(1):9-16

13. Hakim R A, Ali Z, Tjekyan R. Prevalensi dan Faktor Risiko Hipertensi di Kecamatan Ilir Timur II Palembang Tahun 2012. Maj Kedokt Sriwij. 2015;47(1):51-60.

14.Anggara FHD, Prayitno N. Faktor-Faktor yang 


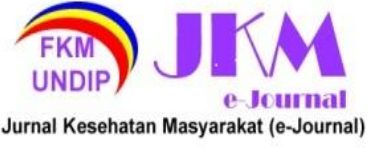

Berhubungan dengan Tekanan Darah di Puskesmas Telaga Murni Cikarang Barat tahun 2012. J IIm Kesehat. 2013;5(1):20-5.

15.Garwahusada E, Wirjatmadi B. Hubungan Jenis Kelamin, Perilaku Merokok, Aktivitas Fisik Dengan Hipertensi Pada Pegawai Kantor. Media Gizi Indones. 2020;15(1):60-5.

16. Babisch W, Pershagen G, Selander J, Houthuijs D, Breugelmans O, Cadum E, et al. Noise annoyance - A modifier of the association between noise level and cardiovascular health? Sci Total Environ. 2013;452-453:50-7.

17. Sheps S. Mayo Clinic Hipertensi, Mengatasi Tekanan Darah Tinggi. Jakarta: Intisari Mediatama; 2005.

18.Sitorus R. Gejala Penyakit dan Pencegahannya. Bandung: Yrama Widya; 2008.

19.Livi LE. Hubungan Antara Konsumsi Alkohol dengan Kejadian Hipertensi pada Laki-Laki Usia 25-65 Tahun di Desa Kapoya Kecamatan Tareran Suluun Kabupaten Minahasa Selatan. J Kesehat Mayarakat Univ Sam Ratulangi. 2015;8(4):1-9.

20.Susiani, Priajaya S, Sirait A. Analisis FaktorFaktor yang Berhubungan Dengan Resiko Kejadian Hipertensi pada Usia Dewasa Muda di Puskesmas Batang Beruh Kecamatan Sidikalang Kabupaten Dairi Tahun 2019. J Chem Inf Model. 2019;3(3):33-43.
Volume 9, Nomor 6, November 2021

ISSN: 2715-5617 / e-ISSN: 2356-3346

http://ejournal3.undip.ac.id/index.php/jkm

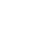

